УдК 664.694

DOI https://doi.org/10.32851/tnv-tech.2021.3.9

\title{
ВПЛИВ ОВОЧЕВИХ ПОРОШКІВ НА ЯКІСТЬ МАКАРОННИХ ВИРОБІВ
}

\author{
Дзюндзя О.В. - кандидат технічних наук, доцент, \\ доцент кафедри інженерії харчового виробництва \\ Херсонського державного аграрно-економічного університету \\ ORCID ID: 0000-0002-1996-7065 \\ Шинкарук М.В. - асистент кафедри інженерії харчового виробництва \\ Херсонського державного аграрно-економічного університету \\ ORCID ID: 0000-0003-3036-6778
}

У статті представлено проблему щзодо раціонального та збалансованого харчування, яка є одним із важливих завдань сучасності. Багато наукових розробок спрямовано на здоров'я людини, вживаються різні заходи з його покращення, однак існує потреба в розширенні асортименту продукиї спеціального призначення. Важливо відзначити, щзо овочеві та ягідні порошки, щуо є концентратами вихідної сировини, дозволяють збагатити страви необхідними нутрієнтами. Метою даної роботи є дослідження можливості виробництва крафтових макаронних виробів із локальної сировини та дослідження впливу великодисперсних порошків із гливи і томатів на якість макаронних виробів у дозуванні 1 ...5\% до маси борошна. Під час огляду розглянуто продукиію різних торгівельних марок. Проаналізовано, щчо додавання до складу макаронних виробів гречаної клітковини дозволяє задовольнити потребу організму в клітковині, щуо сприяє виведенню токсичних речовин і радіонуклідів, покращує метаболізм. Під час проведення дослідження використовували загальноприйняті методи та методики, сировина відповідала вимогам якості й безпечності. Досліджено вплив овочевих порошків різної дисперсності на якість макаронних виробів, спосіб внесення даних порошків. Установлено, що порошки позитивно впливають на міцність, стан поверхні та збереження форми макаронних виробів після варіння. Але для всіх макаронних виробів з овочевими порочками під час варіння характерною є часткова втрата кольору, який надає їм добавка. Зі збільшенням дозування порошків вироби мають більш гладеньку поверхню, набувають міиності, зменшується кількість мікротріщин, покрашується скловидність у зломі. Кислотність знаходиться в межах норми. Збільшення дозування овочевих порошків сприяє покращенню варильних властивостей, підвищенню коефіџієнтів збільшення маси та об'єму порівняно з контролем. Очевидно, щуо із внесенням даних добавок зростає вміст харчових волокон у макаронних виробах, які покращують здатність виробів до набухання. Зроблено висновки, шчо дозування овочевого гливового та томатного порошків під час виробництва макаронних виробів становить 1...3\% до маси борошна. Дані порошки позитивно впливають на міцність, стан поверхні та збереження форми макаронних виробів після варіння, колір яких вони набувають за умов внесення порошку. Важливо відзначити, щуо це дає можливість переробляти борошно з підвищеною здатністю до потемніння.

Ключові слова: порошок гливи, порошок із томатів, макаронні вироби, якість подукиії.

\section{Dzyundzya O.V., Shinkaruk M.V. Influence of vegetable powder on the quality of pasta}

The article presents the problem of rational and balanced nutrition, which is one of the important tasks of today. Many scientific developments are aimed at human health and various measures are being taken to improve it, but there is a need to expand the range of special purpose products. It is important to note that vegetable and berry powders, which are concentrates of raw materials, allow to enrich dishes with the necessary nutrients. The purpose of this work is to study the possibility of production of craft pasta from local raw materials and to study the effect of fine powders of oyster mushrooms and tomatoes on the quality of pasta in dosages of $1 . .55 \%$ by weight of flour. During the literature review the products of different brands were considered. It is analyzed that the addition of buckwheat to pasta allows to meet the body's need for fiber, which promotes the excretion of toxic substances and radionuclides, improves metabolism. During the study, generally accepted methods and techniques were used, raw materials met the requirements of quality and safety. The influence of vegetable powders 
of different dispersion on the quality of pasta, the method of application of these powders and the method of application of powders has been studied. But for all pasta with vegetable powders during cooking is characterized by a partial loss of color, which gives them the additive. With increasing dosage of powders, the products have a smoother surface, gain strength, reduce the number of microcracks, improve glassiness in breakage. Acidity is within normal limits. Increasing the dosage of vegetable powders helps to improve the cooking properties, increase the coefficients of weight and volume compared to the control. It is obvious that with the introduction of these additives increases the content of dietary fiber in pasta, which improves the ability of products to swell. It is concluded that the dosage of vegetable mushroom and tomato powders during the production of pasta is $1 \ldots 3 \%$ by weight of flour. These powders have a positive effect on the strength, condition of the surface and the preservation of the shape of pasta after cooking, the color of which they acquire under the conditions of powder application. It is important to note that this makes it possible to process flour with an increased ability to darken.

Key words: oyster mushroom powder, tomato powder, pasta, quality.

Проблема раціонального та збалансованого харчування є одним із важливих завдань сучасності. Зважаючи на швидкі темпи поширення різноманітних захворювань, що спричинені незбалансованістю раціонів, систематичною нестачею необхідних нутрієнтів, поширенням алергічних реакцій, виникає потреба в пошуку сировини, яка б задовольнила споживачів. Хоча багато наукових розробок спрямовано на здоров'я людини, вживаються різні заходи з його покращення, однак існує потреба в розширенні асортименту продукції спеціального призначення. Популярними стають смарт-виробництва та крафт, які здатні поєднати різноманітні тренди та виготовляти якісну і безпечну продукцію з використанням локальної сировини. Важливо відзначити, що овочеві та ягідні порошки, що є концентратами вихідної сировини, дозволяють збагатити страви необхідними нутрієнтами. Так, наприклад, додавання до тіста порошків дозволяє збільшити вміст харчових волокон, цукрів, азотистих, мінеральних речовин, органічних кислот, вітамінів, натуральних барвників та інших компонентів порівняно з пюре та соками. Тому одним із напрямів раціонального використання місцевих інгредієнтів $є$ виробництво крафтових макаронних виробів, збагачених овочевими та ягідними порошками. Адже завдяки інноваційним технологіям перероблення сировини можна отримати якісний порошкоподібний напівфабрикат 3 певними фізико-хімічними властивостями, що надалі дозволяє виготовити продукт з високими споживчими показниками.

Макаронні вироби користуються значним попитом, а зважаючи на доступність і попит на продукти оздоровчого спрямування, більшість виробників спрямовують свою діяльність на створення виробів спеціального призначення. Наукові розробки науковців знайшли відображення в продукції таких торгівельних марок, як ТМ «МАК-ВАР ЕКОПРОДУКТ», ТМ «Козуб Продукт», ТМ «SoloMia» $[1 ; 2 ; 3 ; 4]$.

В Україні проводиться значна робота з розширення асортименту макаронних виробів профілактичного призначення з метою підвищення імунітету та зниження впливу шкідливих чинників навколишнього середовища. Цьому сприяє використання нетрадиційної сировини й добавок, які містять біологічно активні речовини. Питання розширення асортименту макаронних виробів профілактичного призначення і використання нетрадиційної сировини та природних добавок у виробництві макаронів висвітлювались у праці А.В. Білічук [5].

Науковці Т.П. Голікова та О.О. Орлова дослідили й розробили макаронні вироби 3 порошком глоду колючого, збагачені вітамінами К, Е, групи В, органічними кислотами, макро- та мікроелементами (K, Ca, Мд, $\mathrm{P}, \mathrm{Fe})$, що також містять у порівнянні з контрольним зразком життєво необхідні для організму людини ессенціальні нутрієнти - аскорбінову кислоту, пектинові та Р-активні речовини [6]. 
Аналізуючи сучасні тенденції, ми встановили, що додавання до складу макаронних виробів гречаної клітковини дозволяє задовольнити потребу організму в клітковині, що сприяє виведенню токсичних речовин і радіонуклідів, покращує метаболізм. Науковцями встановлено, що внесення іiі в кількості $30 \%$ забезпечує отримання відмінних органолептичних показників [7].

Встановлено, що перспективним $є$ виробництво безглютенових макаронних виробів з кукурудзи тонкого помолу. Однак для забезпечення гарних органолептичних показників як додаткову сировину рекомендовано додавати желатин, карбоксиметилцелюлозу або використовувати екструдоване кукурудзяне борошно чи здійснювати заварювання частини кукурудзяного борошна тонкого помолу [2; 8].

Популярним $є$ використання харчових порошків як натуральних барвників та джерела поживних нутрієнтів. Так, наприклад, додавання порошку фукуса і льняної муки до рецептури макаронних виробів підвищує вміст мінеральних речовин і вітамінів, а в разі додавання порошку з плодів мушмули в кількості $3 \%$ підвищується поживна цінність і детоксикаційні властивості [9].

Цікавою є ресурсозберігаюча технологія виробництва макаронів з додаванням (2-6\%) лушпиння цибулі як натурального фарбника та джерела важливих речовин: вітамінів (групи В, С, Е, каротин, Р, РP), макро- і мікроелементів (кальцій, магній, фосфор, залізо, йод, цинк, натрій), фітонцидів, 25-ти антиоксидантів, флавоноїдів (кверцетин та рутин) [10].

Метою даної роботи є дослідження можливості виробництва крафтових макаронних виробів із локальної сировини та дослідження впливу великодисперсних порошків із гливи і томатів на якість макаронних виробів у дозуванні $1 \ldots .5 \%$ до маси борошна.

Під час проведення дослідження використовували загальноприйняті методи та методики, сировина відповідала вимогам якості й безпечності.

У роботі досліджено можливість використання порошків у дозуваннях $1 \ldots 5 \%$ до маси борошна. Внесення порошків у кількості меншій ніж 1\% до маси борошна недоцільно для біологічного збагачення продукції, а у разі кількості більше ніж 5\% вироби мають надмірно виражений смак та аромат, притаманний доданому порошку, а також суттєво зростає собівартість виробів.

Досліджували також спосіб внесення порошків: порошок дозували в сухому та у відновленому стані. Внесення в сухому вигляді під час порційного замішування тіста для кращого розподілення порошку проводили поступовим вимішуванням усієї наважки порошку з невеликою кількістю борошна, а потім із всією його кількістю в місильному кориті преса. Для внесення порошку у відновленому вигляді готували суспензію порошку з усією кількістю води, необхідною за рецептурою, за температури $40^{\circ} \mathrm{C}$ і витримували ії протягом $30 \ldots 40$ хв., потім вносили під час замішування тіста традиційним способом як водозбагачувальну суміш.

Встановлено, що внесення порошків позитивно впливає на якість макаронних виробів та їхні варильні властивості (табл. 1). Зі збільшенням дозування порошків вироби мають більш гладеньку поверхню, набувають міцності, зменшується кількість мікротріщин, покращується скловидність у зломі. Кислотність макаронних виробів з використанням $1 \ldots .5 \%$ порошку з гливи зростає на $0,5 \ldots 1$ град. і знаходиться в межах норми. Збільшення дозування овочевих порошків сприяє покращенню варильних властивостей, підвищенню коефіцієнтів збільшення маси та об’єму порівняно з контролем. Очевидно, що із внесенням даних добавок зростає вміст харчових волокон у макаронних виробах, які покращують здатність виробів до набухання. 
Смак макаронних виробів притаманний внесеним овочевим порошкам, прийнятний для макаронних виробів. Але для всіх макаронних виробів з овочевими порошками під час варіння характерною є часткова втрата кольору, який надає їм добавка.

Таблиця 1

Вплив порошку гливи на якість макаронних виробів

\begin{tabular}{|c|c|c|c|c|c|}
\hline \multirow{3}{*}{ Показник } & \multirow{3}{*}{$\begin{array}{c}\text { Контроль } \\
\text { (без добавки) }\end{array}$} & \multicolumn{4}{|c|}{3 порошком, внесеним у вигляді } \\
\hline & & \multicolumn{3}{|c|}{ порошку, \% } & \multirow{2}{*}{$\begin{array}{c}\text { суспен- } \\
\text { 3ї, \% } \\
3\end{array}$} \\
\hline & & 1 & 3 & 5 & \\
\hline \multicolumn{6}{|c|}{ Фізико-хімічні показники } \\
\hline Вологість, \% & 13,2 & 12,7 & 13,0 & 12,5 & 12,5 \\
\hline Кислотність, град. & 1,6 & 1,7 & 2,1 & 2,2 & 2,1 \\
\hline Міцність, Н & 3,8 & 4,1 & 4,6 & - & 4,2 \\
\hline \multicolumn{6}{|c|}{ Варильні властивості: } \\
\hline Колір & білий & $\begin{array}{c}\text { кремовий } 3 \\
\text { рожевим }\end{array}$ & $\begin{array}{l}\text { світло- } \\
\text { сірий }\end{array}$ & сірий & сірий \\
\hline Форма & $\begin{array}{c}\text { частково } \\
\text { втрачається }\end{array}$ & \multicolumn{4}{|c|}{ зберігається, вироби не злипаються } \\
\hline Смак і запах & властиві МВ & $\begin{array}{l}\text { слабкий } \\
\text { грибний }\end{array}$ & грибний & грибний & грибний \\
\hline $\begin{array}{l}\text { Коефіцієнт збільшення } \\
\text { маси, } \mathrm{K}_{\mathrm{m}}\end{array}$ & 1,4 & 1,6 & 2,0 & 2,1 & 2,15 \\
\hline $\begin{array}{l}\text { Коефіцієнт збільшення } \\
\text { об’єму, K }\end{array}$ & 2,0 & 2,0 & 2,4 & 2,5 & 2,5 \\
\hline $\begin{array}{l}\text { Кількість СР, що } \\
\text { перейшли в ВВ, \% }\end{array}$ & 8,0 & 7,7 & 7,3 & 8,6 & 8,5 \\
\hline $\begin{array}{l}\text { Кількість цукрів, що } \\
\text { перейшли у ВВ, \% до СР }\end{array}$ & 0,9 & - & 1,7 & - & 2,1 \\
\hline
\end{tabular}

Кількість сухих речовин, що перейшли у варильну воду під час варіння виробів 3 добавками, незначно зменшується під час внесення в тісто 1\% порошку, а у разі подальшого підвищення дозування збільшується. Це може бути наслідком не погіршення властивостей виробів, а високого вмісту в овочевих і ягідних порошках цукрів (більше ніж $30 \%$ ), які є водорозчинними сполуками. Тому визначали кількість цукрів, що перейшли у варильну воду. Встановлено (табл. 1), що під час внесення порошків кількість цукрів у варильній воді зростає. Ця кількість відповідає вмісту цукрів у овочевих порошках, що вносяться в макаронні вироби. Решта сухих речовин, які представлені іншими сполуками, зменшується. Таке явище може бути зумовлене тим, що вироби з добавкою мають щільну й міцнішу структуру, яка сприяє зменшенню переходу сухих речовин у воду. Але цукри, які містяться в порошках, розчиняються у воді під час замішування тіста, у процесі сушіння макаронних виробів дифундують із вологою до периферійних шарів і під час варіння розчиняються в гарячій воді. Унаслідок цього загальна кількість сухих речовин у варильній воді зростає. 
Таблиця 2

Вплив порошку томатів на якість макаронних виробів

\begin{tabular}{|c|c|c|c|c|}
\hline \multirow[b]{2}{*}{ Показник } & \multicolumn{4}{|c|}{ Під час внесення порошку, \% до маси борошна } \\
\hline & $\begin{array}{c}\text { Контроль } \\
\text { (без добавки) }\end{array}$ & 1 & 3 & 5 \\
\hline \multicolumn{5}{|c|}{ Фізико-хімічні показники } \\
\hline Вологість, \% & 12,4 & 12,6 & 12,6 & 12,0 \\
\hline Кислотність, град. & 3,2 & 3,7 & 4,2 & 4,7 \\
\hline \multicolumn{5}{|c|}{ Варильні властивості } \\
\hline Колір & кремовий & рожевий & червоний & багряний \\
\hline Форма & $\begin{array}{c}\text { частково } \\
\text { втрачається }\end{array}$ & & \multicolumn{2}{|c|}{$\begin{array}{c}\text { зберігається, вироби } \\
\text { не злипаються }\end{array}$} \\
\hline Смак і запах & \multicolumn{2}{|c|}{ властивий макаронним виробам } & \multicolumn{2}{|c|}{ відчутний кислий смак } \\
\hline $\begin{array}{l}\text { Коефіцієнт збільшення } \\
\text { маси } \mathrm{K}_{\text {м }}\end{array}$ & 2,0 & 2,2 & 2,4 & 2,3 \\
\hline $\begin{array}{l}\text { Коефіцієнт збільшення } \\
\text { об’єму К }\end{array}$ & 2,2 & 2,4 & 2,5 & 2,0 \\
\hline $\begin{array}{l}\text { Кількість сухих речо- } \\
\text { вин, що перейшли у } \\
\text { варильну воду, \% }\end{array}$ & 11,0 & 10,6 & 11,3 & 12,0 \\
\hline
\end{tabular}

Незначно впливає на міцність виробів та їхню якість спосіб внесення порошків великої дисперсності. Вироби дещо міцніші, коли добавка внесена у сухому вигляді, можливо тому, що в цьому випадку колоїди борошна і пектин конкурують у дозуванні води і гідратується білок борошна більшою мірою, ніж під час внесення пектину в набухлому вигляді. Внесення гливового високодисперсного порошку в гідратованому вигляді дає найбільш відчутне підвищення якості макаронних виробів. Але, як видно з таблиці 1, міцність виробів корелює із значеннями коефіцієнтів збільшення маси та об’єму. Тобто чим міцніші вироби, тим меншу кількість води вони можуть увібрати за однаковий час варіння.

У результаті дослідження впливу високодисперсного порошку томату на якість і варильні властивості макаронних виробів (табл. 2) установлено позитивний вплив на стан поверхні, стан у зламі, міцність, а також збереження форми виробів після варіння. Відчутно зростають коефіцієнти збільшення маси та об'єму. Проте кислотність макаронних виробів підвищується більш відчутно порівняно $з$ макаронними виробами з гливовим порошком, а саме на 0,5 .. 1,5 град.

На якість макаронних виробів краще впливають високодисперсні овочеві порошки. Так, наприклад, вироби з високодисперсними порошками з томатів мають вищі показники $\mathrm{K}_{\mathrm{M}}$ i $\mathrm{K}_{\mathrm{v}}$ більш ніж у виробів 3 великодисперсними порошками із гливи (табл. 1 і табл. 2).

Висновки. Обгрунтовано, що дозування овочевого гливового та томатного порошків під час виробництва макаронних виробів становить $1 \ldots 3 \%$ до маси борошна. Дані порошки позитивно впливають на міцність, стан поверхні та збереження форми макаронних виробів після варіння, колір яких вони набувають за умови внесення порошку. Важливо відзначити, що це дає можливість переробляти борошно з підвищеною здатністю до потемніння. 


\section{СПИСОК ВИКОРИСТАНОЇ ЛІТЕРАТУРИ:}

1. Сенсорна характеристика цільнозернових та овочевих макаронних виробів. Науковий вісник Полтавського університету економіки і торгівлі / О.О. Горячова та ін. 2018. № 1 (85). С. 104-113.

2. Рожно О.В. Розробка технології безглютенових макаронних виробів : автореф. дис. ... канд. техн. наук : 05.18.01 «Технологія хлібопекарських продуктів, кондитерських виробів та харчових концентратів» ; Національний університет харчових технологій. Київ, 2018. 22 с.

3. Мазаракі А.А., Пересічний М.І., Кравченко М.Ф. Технологія харчових продуктів функціонального призначення : монографія. Київ : Київ. нац. торг.-екон. ун-т, 2012.

4. Ринок макаронних виробів в Україні: гості з Європи можуть відчувати себе як вдома. URL: https://pro-consulting.ua/ua/pressroom/rynok-makaronnyh-izdelij-vukraine-gosti-iz-evropy-mogut-chuvstvovat-sebya-kak-doma

5. Білічук А.В. Шляхи розширення асортименту макаронних виробів профілактичного призначення Хлібопекарська і кондитерська промисловість України. 2012. № 2. C. 30-32.

6. Голікова Т.П., Орлова О.О. Макаронні вироби з порошком глоду. Патент на корисну модель № 13495. 2017.

7. Kalyna V., Hola A. Макаронні вироби на основі клітковини гречаної. Вісник Національного технічного університету «ХПІ». Серія: Нові рішення у сучасних технологіях. 2018. № 45 (1321). С. 160-165.

8. Rozhno O., Podobiy O., Yurchak V. Research of the Rheological Properties of Gelatine Solutions for Production of Gluten-Free Pasta. Ukrainian food journal: internatinal scientific journal. 2016. № 5 (2). P. 290-298.

9. Разработка рецептуры макаронных изделий с повышенной пищевой ценностью. Технология $u$ товароведение инноващионных пищеевых продуктов / Э.Р. Биккулова и др. 2019. № 5. С. 62-68.

10. Чорна А.І., Дричик М.Ю. Макаронні вироби підвищеної харчової цінності. Патент на корисну модель № 143119. 2020.

\section{REFERENCES:}

1. Horyachova, O. O., Nazarenko, V. O., Ofilenko, N. O., Kotova, Z. YA. (2018). Sensorna kharakterystyka tsil'nozernovykh ta ovochevykh makaronnykh vyrobiv. [Sensory characteristics of whole grain and vegetable pasta.]. Naukovyy visnyk Poltavs'koho universytetu ekonomiky ta torhivli. № 1 (85). S. 104-113.

2. Rozhno, O. V. (2018). Rozrobka tekhnolohiy bez hlyutenovykh makaronnykh vyrobiv: avtoref. [Development of technology of gluten-free pasta: author's ref.]. dys. ... kand. tekhn.nauk: 05.18.01 «Tekhnolohiya khlibopekars'kykh produktiv, kondyters'kykh vyrobiv ta kharchovykh kontsentrativ»; Natsional'nyy universytet kharchovykh tekhnolohiy. Kyyiv, $22 \mathrm{~s}$.

3. Mazaraki, A. A., Peresichnyy, M. I., \& Kravchenko, M. F. (2012). Tekhnolohiya kharchovykh produktiv funktsional'noho pryznachennya: monohrafiya. [Technology of food products for functional purposes]. K.: Kyyiv. nats. torh.-ekon. un-t.

4. Rynok makaronnykh vyrobiv v Ukrayini: hosti z Yevropy mozhut' vidchuvaty sebe yak vdoma. [The pasta market in Ukraine: guests from Europe can feel at home]. [Elektronnyy resurs]-rezhym dostupu: https://pro-consulting.ua/ua/pressroom/ rynok-makaronnyh-izdelij-v-ukraine-gosti-iz-yevropy-mohut-chuvstvovat'-sebyakak-doma

5. Bilichuk A. V. (2012). Shlyakhy rozshyrennya asortymentu makaronnykh vyrobiv profilaktychnoho pryznachennyaю. [Ways to expand the range of pasta for preventive purposes]. Khlibopekars'ka ta kondyters'ka promyslovist' Ukrayiny. № 2. S. 30-32.

6. Holikova T.P., Orlova O.O. (2017). Makaronni vyroby z poroshkom svitu. [Pasta with hawthorn powder]. Patent na model' vykorystannya № 13495. 
7. Kalyna V. ta Khola A. (2018). Makaronni vyroby na osnovi klitkovyny hrechanoyi. [Pasta based on buckwheat fiber]. Visnyk Natsional'noho tekhnichnoho universytetu «KHPI». Seriya: Novi rishennya u suchasnykh tekhnolohiyakh, № 45 (1321). S. 160-165.

8. Rozhno O., Podobiy O., Yurchak V. (2016). Doslidzhennya reolohichnykh vlastyvostey zhelatynovykh rozchyniv dlya vyrobnytstva bez hlyutenovoyi pasty. [Research of the Rheological Properties of Gelatine Solutions for Production of GlutenFree Pasta]. Ukrayins'kyy kharchovyy zhurnal: mizhnarodnyy naukovyy zhurnal. № 5 (2). R 290-298.

9. Bykkulova, É. R., Chernenkov, E. N., Chernenkova, A. A., Myronova, Y. V., \& Badamshyna, E. V. (2019). Rozrobka retseptiv makaronnykh vyrobiv z pidvyshchenoyu pishchevoyu tsennistyu. [Development of a recipe for pasta with high nutritional value]. Tekhnolohiya ta tovarovedennya innovatsiynykh pishchevykh produktiv. № 5. S. 62-68.

10. Chorna, A. I., Drychyk, M. YU. (2020). Makaronni vyroby zbil'shuyut' kharchovu vartist'. [Pasta of high nutritional value]. Patent na model' vykorystannya № 143119. 2020. 